\title{
EFEKTIVITAS SISTEM PENGENDALIAN INTERN PADA KINERJA INSTANSI PEMERINTAH DI DINAS PENDAPATAN DAERAH KABUPATEN MINAHASA UTARA
}

\author{
Renli Ferrari Daud Sondakh \\ David Paul Elia Saerang \\ Lidia M. Mawikere \\ Fakultas Ekonomi Dan Bisnis, Jurusan Akuntansi \\ Universitas Sam Ratulangi, Manado \\ Email :calvaryrenly@yahoo.com
}

\begin{abstract}
In a government organization requires their internal control systems due to their system of internal control activities undertaken by government agencies more effective and avoid fraud and keep the business property of parties who are not responsible. The object of this research is the Dinas Pendapatan Daerah Kabupaten Minahasa Utara. The purpose of this study to analyze the effectiveness of the internal control system on the performance of government agencies in the Dinas Pendapatan Daerah Kabupaten Minahasa Utara. The method used is descriptive qualitative. The results showed that the internal control system used Dinas Pendapatan Daerah Kabupaten Minahasa Utara effective and sufficient for compliance with the Internal Control System of the Government that has been set by the government based on Government Regulation No. 60 of 2008, so that the achievement of revenue receipts and the realization of the region in 2015 is said to be very effective.
\end{abstract}

Keywords: Government Accounting, Internal Control System of the Government, Performance, effectiveness, Dinas Pendapatan Daerah

\section{PENDAHULUAN}

\section{Latar belakang}

Negara Indonesia merupakan negara kepulauan yang mempunyai wilayah yang terdiri dari beribu-ribu pulau serta susunan masyarakatnya terdiri dari berbagai suku bangsa yang berbeda-beda. Dalam hal ini pemerintah berupaya untuk meningkatkan dan melakukan pemerataan pembangunan. Hal ini untuk mencapai tujuan Negara Kesatuan Republik Indonesia yaitu masayarakat adil dan makmur berdasarkan Pancasila dan Undang-Undang Dasar 1945. Dalam rangka pelaksanaan otonomi daerah setiap daerah dituntut untuk dapat mengatur dan membiayai pengeluarannya sendiri untuk itu diperlukan dana yang memadai. Oleh karena itu, melalui UU No.23 Tahun 2014 tentang Pemerintah Daerah yang telah di revisi menjadi UU No.9 Tahun 2015 dan UU No.33 Tahun 2004 tentang Perimbangan Keuangan Antara Pemerintah Pusat dan Pemerintah Daerah untuk memperoleh dana dapat ditingkatkan. Sebagai daerah otonomi, daerah yang digali dari dalam wilayah daerah bersangkutan yang terdiri dari hasil pajak daerah, hasil retribusi daerah, pengelolaan kekayaan yang dipisahkan dan lain-lain pendapatan daerah yang sah yang menjadi sumber Pendapatan Asli Daerah (PAD) maka pemerintah mempunyai kewajiban untuk meningkatkan kesejahteraan rakyat serta menjaga dan memelihara ketentraman dan ketertiban masyarakat.

Undang-undang di bidang keuangan negara membawa implikasi perlunya sistem pengelolaan keuangan negara yang lebih akuntabel dan transparan. Dengan demikian maka penyelenggaraan kegiatan pada suatu instansi pemerintah, mulai dari perencanaan, pelaksanaan, pengawasan, sampai dengan pertanggungjawaban, harus dilaksanakan secara tertib, terkendali, serta efisien dan efektif. Untuk itu dibutuhkan suatu sistem yang dapat memberi keyakinan memadai bahwa penyelenggaraan kegiatan pada suatu instansi pemerintah dapat mencapai tujuannya secara efisien dan efektif, melaporkan pengelolaan keuangan negara secara andal, mengamankan aset negara, dan mendorong ketaatan terhadap peraturan perundang-undangan. Sistem ini dikenal sebagai Sistem Pengendalian Intern yang dalam penerapannya harus memperhatikan rasa keadilan dan kepatutan serta 
mempertimbangkan ukuran, kompleksitas, dan sifat dari tugas dan fungsi instansi pemerintah tersebut.

Didalam Dinas Pendapatan Daerah Kabupaten Minahasa Utara, pengendalian internal sangat penting diperlukan, karena dengan adanya pengendalian internal maka kegiatan yang dilakukan oleh instansi pemerintah lebih terarah dan terhindar dari kecurangan dan menjaga harta perusahaan dari pihak-pihak yang tidak bertanggung jawab. Pihak-pihak yang tidak bertanggung jawab adalah orang yang melanggar tugas dan wewenang yang telah di tetapkan oleh perusahaan, untuk itu pengendalian internal perlu diperhatikan dan diterapkan secara benar oleh instansi pemerintah.

Sistem Pengendalian Intern dalam Dinas Pendapatan Daerah Kabupaten Minahasa Utara sangat penting, karena didalam internal control terdapat beberapa unsur yaitu struktur organisasi dapat memisahkan fungsi-fungsi operasional, penerimaan, penyimpanan dan pencatatan, karena dengan adanya pemisahan fungsi operasional kecurangan dapat dihindari. Pemisahan fungsi-fungsi ini dapat diharapkan mencegah timbulnya kecurangan-kecurangan dalam penerimaan pajak daerah. Dalam unsur internal control juga terdapat sistem wewenang dan prosedur pembukuan untuk mengadakan pengawasan selektif terhadap operasi dan transaksi-transaksi yang terjadi dan juga untuk mengklasifikasikan data akuntansi dengan tepat dan praktek-praktek yang sehat.

Didalam akuntansi, pengendalian intern yang berlaku dalam organisasi/instansi merupakan faktor yang menentukan keandalan laporan keuangan yang dihasilkan oleh organisasi tersebut. Studi ini dapat memberikan manfaat sebagai sumbangan pemikiran kepada instansi pemerintah agar bisa mengoptimalkan pengawasan internal seperti lingkungan pengendalian, dalam menilai resiko, aktivitas pengendalian, informasi dan komunikasi serta pemantauan untuk mencapai tujuan perusahaan, guna mencapai tujuan maka pemerintah daerah harus mengelola dana administrasi Pendapatan Asli Daerah secara efektif dan efisien, sehingga akan terwujud otonomi daerah yang nyata dan bertanggung jawab yang telah diterapkan oleh Dinas Pendapatan Daerah Kabupaten Minahasa Utara dalam capaian kinerja instansi pemerintahan, maka judul penelitian ini "Efektivitas Sistem Pengendalian Intern Pada Kinerja Instansi Pemerintah di Dinas Pendapatan Daerah Kabupaten Minahasa Utara".

\section{Rumusan Masalah}

Sesuai dengan latar belakang masalah, maka yang menjadi permasalahan dalam penelitian ini adalah "Bagaimana keefektivan penerapan sistem pengendalian intern pada Dinas Pendapatan Daerah Kabupaten Minahasa Utara?"

\section{Tujuan Penelitan}

Tujuan yang ingin dicapai dalam penelitian ini adalah untuk menganalisis efektifitas sistem pengendalian intern pada kinerja instansi pemerintahan di Dinas Pendapatan Daerah Kabupaten Minahasa Utara.

\section{Manfaat Penelitian}

Hasil penelitian ini diharapkan dapat member manfaat antara lain sebagai berikut.

1. Menjadi masukan bagi instansi pemerintahan di Dinas Pendapatan Daerah Kabupaten Minahasa Utara dalam meningkatkan Sistem Pengendalian Intern Pemerintah.

2. Menjadi bahan referensi bagi penelitian selanjutnya yang akan mengadakan penelitian tentang Sistem Pengendalian Intern Pemerintah.

\section{Pengertian Akuntansi}

\section{TINJAUAN PUSTAKA}

Akuntansi adalah sistem informasi yang mengukur aktivitas bisnis, pemrosesan data menjadi laporan, dan mengkomunikasikan hasilnya pada para pengambil keputusan (Pontoh, $2013: 1$ ).

American Accounting Association mendefinisikan akuntansi sebagai proses mengidentifikasi, mengukur, dan melaporkan informasi ekonomi, untuk memungkinkan adanya penilaian dan keputusan yang jelas dan tegas bagi mereka yang menggunakan informasi tersebut dalam buku (Sadeli, 2012:2). 


\section{Pengertian Akuntansi Sektor Publik}

Sujarweni (2015:1) menyatakan Akuntansi adalah suatu aktivitas jasa yang terdiri dari mencatat, mengklasifikasikan, dan melaporkan kejadian atau transaksi ekonomi yang akhirnya akan menghasilkan suatu informasi keuangan yang akan dibutuhkan oleh pihak-pihak tertentu untuk pengambilan keputusan. Sedangkan sektor publik adalah semua yang berhubungan dengan kepentingan publik dan tentang penyediaan barang dan jasa yang ditunjukan untuk publik, dibayarkan melalui pajak dan pendapatan Negara lainnya yang sudah diatur dalam hukum. Jadi akuntansi sektor publik dapat didefinisikan sebagai aktivitas jasa yang terdiri dari mencatat, menghasilkan, dan melaporkan kejadian atau transaksi ekonomi yang akhirnya akan menghasilkan suatu informasi keuangan yang akan dibutuhkan oleh pihak-pihak tertentu untuk pengambilan keputusan, yang diterapkan pada pengelolaan dana publik di lembaga-lembaga tinggi Negara dan departemendepartemen dibawahnya.

\section{Pengertian Akuntansi Pemerintahan}

Deddi (2012:1) menyatakan akuntansi pemerintahan adalah aplikasi akuntansi di bidang keuangan negara, khususnya pada tahapan pelaksanaan anggaran, termasuk segala pengaruh yang ditimbulkannya, baik yang bersifat seketika maupun yang lebih permanen pada semua tingkatan dan unit pemerintahan, tuntutan transparansi dan akuntabilitas publik atas dana-dana masyarakat yang dikelola pemerintah memunculkan kebutuhan atas penggunaan akuntansi dalam mencatat dan melaporkan kinerja pemerintahan. Selanjutnya menurut (Halim, et al, 2014:14) akuntansi pemerintahan memiliki kaitan yang erat dengan penerapan dan perlakuan akuntansi pada domain publik. Secara kelembagaan, domain publik antara lain meliputi badan-badan pemerintahan, perusahaan milik Negara dan daerah, yayasan, organisasi masyarakat dan organisasi massa, lembaga swadaya masyarakat, dan organisasi nirlabanya.

Akuntansi pemerintahan mengkhususkan dalam pencatatan dan pelaporan transaksi-transaksi yang terjadi pada badan pemerintahan. Dari beberapa pendapat para ahli dapat disimpulkan bahwa akuntansi pemerintahan adalah pengaplikasian akuntansi di bidang keuangan pemerintahan yang khususnya pada tahapan pencatatan, pelaporan, dan pelaksanaan anggaran termasuk segala pengaruh yang ditimbulkannya pada suatu tingkat atau unit pemerintahan, baik itu bersifat semntara atau pun permanen (Nordiawan, 2012:4).

\section{Sistem Pengendalian Intern}

Menurut Matamande, et al. (2012) Pengertian sistem pengendalian intern adalah menempatkan satu set kebijakan organisasi dan disetujui proses pengendalian intern dibuat oleh manajemen suatu organisasi untuk pura-pura mencapai tujuan utama manajemen untuk memastikan bahwa bisnis beroperasi sempurna.

Sari (2015) menyatakan bahwa salah satu upaya yang dapat dilakukan untuk meminimalisir tindakan kecurangan adalah melalui peningkatan sistem pengendalian intern. Dalam Peraturan Pemerintah Republik Indonesia Nomor 60 Tahun 2008 Tentang Sistem Pengendalian Intern Pemerintah dijelaskan bahwa pengendalian intern merupakan proses yang intergral pada tindakan dan kegiatan yang dilakukan secara terus menerus oleh pimpinan dan seluruh pegawai untuk memberikan keyakinan memadai atas tercapainya tujuan organisasi melalui kegiatan yang efektif dan efesien, keandalan pelaporan keuangan, pengamanan aset negara, dan ketaatan terhadap peraturan perundangundangan.

\section{Kinerja}

Mahsun (25:2014) menyatakan kinerja (performance) adalah gambaran mengenai tingkat pencapaian pelaksanaan suatu kegiatan/program/kebijakan dalam mewujudkan sasaran, tujuan, misi dan visi organisasi yang tertuang dalam strategi planning suatu organisasi. Istilah kinerja sering digunakan untuk menyebut prestasi atau tingkat keberhasilan individu maupun kelompok individu. Kinerja bias diketahui hanya jika individu atau kelompok individu terssebut mempunyai kriteria keberhasilan yang telah ditetapkan. Kriteria keberhasilan ini berupa tujuan-tujuan atau target, kinerja seseorang hendak dicapai. Tanpa ada tujuan atau target, kinerja seseorang atau organisasi tidak mungkin dapat diketahui karena tidak ada tolak ukurnya. Sedangkan pengukuran kinerja adalah suatu 
proses penilaian kemajuan pekerjaan terhadap tujuan dan sasaran yang telah ditentukan sebelumnya, termasuk informasi atas efisiensi penggunaan sumber daya dalam menghasilkan barang dan jasa, kualitas barang dan jasa (seberapa baik barang dan jasa diseraahkan kepada pelanggan dan sampai seberapa jauh pelanggan terpuaskan), hasil kegiatan dibandingkan dengan maksud yang diinginkan, dan efektivitas tindakan dalamencapai tujuan.

Putri (2014) menyatakan kinerja merupakan suatu pencapaian atas apa yang telah direncanakan, baik oleh pribadi maupun organisasi. Kinerja diartikan sebagai aktivitas terukur dari suatu entitas selama periode tertentu sebagai bagian dari ukuran keberhasilan pekerjaan. Selanjutnya "pengukuran kinerja adalah suatu proses sistematis untuk menilai apakah program kegiatan yang telah direncanakan telah dilaksanakan sesuai dengan rencana tersebut, dan yang lebih penting adalah apakah telah mencapai keberhasilan yang telah ditargetkan pada saat perencanaan".

\section{Konsep Pendapatan Asli Daerah}

Menurut (Halim, 2013:101) pendapatan asli daerah merupakan semua penerimaan daerah yang berasal dari sumber ekonomi asli daerah. Kelompok Pendapatan Asli Daerah dipisahkan menjadi empat jenis pendapatan yaitu, pajak daerah, retribusi daerah, hasil pengelolaan kekayan milik daerah yang dipisahkan, dan lain-lain PAD yang sah.

Menurut penelitian Damayanti (2015) sektor perpajakan memberikan kontribusi signifikan terhadap pendapatan pemerintah Negara. penerimaan pajak adalah pendapatan yang dapat diandalkan sebagai pembiayaan pembangunan, terutama pembangunan pemerintah daerah. Sedangkan menurut penelitian Puspitasari (2014) PAD merupakan salah satu sumber penerimaan daerah yang bertujuan memberikan kewenangan kepada Pemerintah Daerah untuk mendanai pelaksanaan pembangunan dan otonomi daerah sesuai dengan potensi daerah sebagai wujud desentralisasi. PAD terdiri dari pajak daerah, retribusi daerah, hasil pengelolaan kekayaan daerah yang dipisahkan dan PAD lain-lain yang sah.

\section{Efektivitas}

Mahmudi (2010:92) mengatakan bahwa suatu organisasi, program, atau kegiatan dinilai efektif apabila output yang dihasilkan bisa memenuhi tujuan yang diharapkan, karena output yang dihasilkan organisasi sektor publik lebih banyak bersifat output tidak berwujud yang tidak mudah dikuantifikasi, pengukuran efektivitas sering menghadapi kesulitan. Kesulitan dalam pengukuran efektivitas tersebut karena pencapaian hasil seiring tidak diketahui dalam jangka pendek, tetapi dalam jangka panjang setelah program berakhir. Jadi ukuran efektivitas biasanya dinyatakan secara kualitatif untuk pernyataan saja. Outcome juga sering kali dipengaruhi oleh hal-hal diluar kendali pemerintah, misalnya target jumlah panen padi pada musim tertentu. Meskipun berbagai output yang mendukung hal tersebut telah dihasilkan, faktor cuaca terkadang lebih menentukan.

Dengan mengetahui perbandingan antara realisasi penerimaan dengan target yang ditetapkan maka penilaian kriteria efektivitas dapat diukur berdasarkan Kepmendagri No. 690.900-327 tahun 1996 tentang pedoman penilaian dan kinerja keuangan yaitu sebagai berikut

Tabel 2.1

Kriteria kinerja keuangan (efektivitas)

\begin{tabular}{|c|c|}
\hline Tingkat Ketaatan Sampel & Kriteria Efektif \\
\hline $100 \%$ keatas & Sangat Efektif \\
\hline $90 \%-100 \%$ & Efektif \\
\hline $80 \%-90 \%$ & cukup Efektif \\
\hline $60 \%-80 \%$ & Kurang efektif \\
\hline Kurang dari $60 \%$ & Tidak efektif \\
\hline
\end{tabular}

Sumber: Depdagri, Kepmendagri No. 690.900-327 Tahun 1996 


\section{Sistem Pengendalian Intern Pemerintah menurut PP No.60 Tahun 2008}

System Pengendalian Internal Pemerintah (SPIP) menerut UU No.60 Tahun 2008 Pasal 1 menjelaskan bahwa sebagai berikut.

1. Sistem Pengendalian Intern adalah proses yang integral pada tindakan dan kegiatan yang dilakukan secara terus menerus oleh pimpinan dan seluruh pegawai untuk memberikan keyakinan memadai atas tercapainya tujuan organisasi melalui kegiatan yang efektif dan efisien, keandalan pelaporan keuangan, pengamanan aset negara, dan ketaatan terhadap peraturan perundang-undangan.

2. Sistem Pengendalian Intern Pemerintah, yang selanjutnya disingkat SPIP, adalah Sistem Pengendalian Intern yang diselenggarakan secara menyeluruh di lingkungan pemerintah pusat dan pemerintah daerah.

3. Pengawasan Intern adalah seluruh proses kegiatan audit, reviu, evaluasi, pemantauan, dan kegiatan pengawasan lain terhadap penyelenggaraan tugas dan fungsi organisasi dalam rangka memberikan keyakinan yang memadai bahwa kegiatan telah dilaksanakan sesuai dengan tolok ukur yang telah ditetapkan secara efektif dan efisien untuk kepentingan pimpinan dalam mewujudkan tata kepemerintahan yang baik.

4. Badan Pengawasan Keuangan dan Pembangunan, yang selanjutnya disingkat BPKP, adalah aparat pengawasan intern pemerintah yang bertanggung jawab langsung kepada Presiden.

5. Inspektorat Jenderal atau nama lain yang secara fungsional melaksanakan pengawasan intern adalah aparat pengawasan intern pemerintah yang bertanggung jawab langsung kepada menteri/pimpinan lembaga.

6. Inspektorat Provinsi adalah aparat pengawasan intern pemerintah yang bertanggung jawab langsung kepada gubernur.

7. Inspektorat Kabupaten/Kota adalah aparat pengawasan intern pemerintah yang bertanggung jawab langsung kepada bupati/walikota.

8. Kementerian negara adalah organisasi dalam Pemerintahan Republik Indonesia yang dipimpin oleh menteri untuk melaksanakan tugas dalam bidang tertentu.

9. Lembaga adalah organisasi non-kementerian Negara dan instansi lain pengguna anggaran yang dibentuk untuk melaksanakan tugas tertentu berdasarkan Undang-Undang Dasar Negara Republik Indonesia Tahun 1945 atau peraturan perundang-undangan lainnya.

10. Pemerintah daerah adalah gubernur, bupati, atau walikota, dan perangkat daerah sebagai unsure penyelenggara pemerintah daerah.

11. Instansi Pemerintah adalah unsur penyelenggara pemerintahan pusat atau unsur penyelenggara pemerintahan daerah.

Pasal 2

1. Untuk mencapai pengelolaan keuangan negara yang efektif, efisien, transparan, dan akuntabel, menteri/pimpinan lembaga, gubernur, dan bupati/walikota wajib melakukan pengendalian atas penyelenggaraan kegiatan pemerintahan.

2. Pengendalian atas penyelenggaraan kegiatan pemerintahan sebagaimana dimaksud pada ayat (1), dilaksanakan dengan berpedoman pada SPIP sebagaimana diatur dalam Peraturan Pemerintah ini.

3. SPIP sebagaimana dimaksud pada ayat (2) bertujuan untuk memberikan keyakinan yang memadai bagi tercapainya efektivitas dan efisiensi pencapaian tujuan penyelenggaraan pemerintahan negara, keandalan pelaporan keuangan, pengamanan asset negara, dan ketaatan terhadap peraturan perundang-undangan.

Pasal 3, SPIP terdiri atas unsur-unsur sebagai berikut.

1. Lingkungan pengendalian.

Pimpinan Instansi Pemerintah wajib menciptakan dan memelihara lingkungan pengendalian yang menimbulkan perilaku positif dan kondusif untuk penerapan Sistem Pengendalian Intern dalam lingkungan kerjanya, melalui hal-hal berikut ini:

a. penegakan integritas dan nilai etika;

b. komitmen terhadap kompetensi;

c. kepemimpinan yang kondusif;

d. pembentukan struktur organisasi yang sesuai dengan kebutuhan; 
e. pendelegasian wewenang dan tanggung jawab yang tepat;

f. penyusunan dan penerapan kebijakan yang sehat tentang pembinaan sumber daya manusia;

g. perwujudan peran aparat pengawasan intern pemerintah yang efektif; dan

h. hubungan kerja yang baik dengan Instansi Pemerintah terkait.

2. Penilaian risiko.

Penilaian risiko diawali dengan penetapan maksud dan tujuan Insatnsi Pemerintah yang jelas dan konsisten baik pada tingkat kegiatan. Selanjutnya Instansi Pemerintah mengidentifikasi secara efisien dan efektif risiko yang dapat menghambat pencapaian tujuan tersebut, baik yang bersumber dari dalam maupun dari luar instansi. Terhadap risiko yang telah diidentifikasi dianalisis untuk mengetahui pengaruhnya terhadap pencapaian tujuan. Pimpinan Instansi Pemerintah merumuskan pendekatan manajemen risiko dan kegiatan pengendalian risiko yang diperlukan untuk memperkecil risiko. Pimpinan Instansi Pemerintah menggunakan metodologi identifikasi risiko yang sesuai untuk tujuan Instansi Pemerintah dan tujuan pada tingkatan kegiatan secara komprhensif. Hal-hal yang perlu dipertimbangkan adalah sebagai berikut.

a. Metode kualitatif dan kuantitatif digunakan untuk mengidentifikasi risiko dan menentukan peringkat risiko relative secara terjadwal dan berkala.

b. Cara suatu resiko diidentifikasi, diperingkat, dianalisis, dan diatasi telah dikomunikasikan kepada pegawai yang berkepentingan.

c. Pembahasan identifikasi risiko dilakukan pada rappat tingkat Pimpinan Instansi Pemerintah.

d. Identifikasi risiko merupakan bagian dari prakiraan rencana jangka pendek dan jangka panjang, serta rencana strategis.

e. Identifikasi risiko merupakan hasil dari pertimbangan atas temuan autdit, hasil evaluasi, dan penilaian lainnya.

f. Risiko yang diidentifikasi pada tingkat pegawai dan pimpinan tngkat menengah menjadi perhatian pimpinan Instansi Pemerintah yang lebih tinggi.

3. Kegiatan pengendalian.

Kegiatan Pengendalian pada instansi pemerintah sebagai berikut:

a. reviu atas kinerja Instansi Pemerintah yang bersangkutan;

b. pembinaan sumber daya manusia;

c. pengendalian atas pengelolaan sistem informasi;

d. pengendalian fisik atas aset;

e. penetapan dan reviu atas indikator dan ukuran kinerja;

f. pemisahan fungsi;

g. otorisasi atas transaksi dan kejadian yang penting;

h. pencatatan yang akurat dan tepat waktu atas transaksi dan kejadian;

i. pembatasan akses atas sumber daya dan pencatatannya;

j. akuntabilitas terhadap sumber daya dan pencatatannya; dan

k. dokumentasi yang baik atas Sistem Pengendalian Intern serta transaksi dan kejadian penting.

4. Informasi dan komunikasi.

Pimpinan Instansi Pemerintah wajib mengidentifikasi, mencatat, dan mengkomunikasikan informasi dalam bentuk dan waktu yang tepat. Dalam Pasal 42 Komunikasi atas informasi sebagaimana dimaksud dalam Pasal 41 wajib diselenggarakan secara efektif. Untuk menyelenggarakan komunikasi yang efektif sebagaimana pimpinan Instansi Pemerintah harus sekurang-kurangnya melakukan hal-hal berikut ini:

a. menyediakan dan memanfaatkan berbagai bentuk dan sarana komunikasi dan

b. mengelola, mengembangkan, dan memperbarui sistem informasi secara terus menerus.

5. Pemantauan pengendalian intern.

Pimpinan Instansi Pemerintah wajib melakukan pemantauan Sistem Pengendalian Intern.Pemantauan Sistem Pengendalian Intern sebagaimana dimaksud dilaksanakan melalui 
pemantauan berkelanjutan, evaluasi terpisah, dan tindak lanjut rekomendasi hasil audit dan reviu lainnya.

\section{Jenis Penelitian}

\section{METODE PENELITIAN}

Penelitian ini merupakan penelitian deskriptif. Menurut Sugiyono (2012:29) deskriptif adalah yang digunakan untuk menggambarkan atau menganalisis suatu hasil penelitian tetapi tidak digunakan untuk membuat kesimpulan yang lebih luas. Oleh Karena itu melalui penelitian deskriptif ini penulis akan memberikan gambaran mengenai sistem pengendalian intern pemerintah yang meliputi, lingungan pengendalian, penilaian resiko, kegiatan pengendalian, informasi dan komunikasi dan pemantauan pengendalian intern, pada kinerja instansi pemerintah di Dinas Pendapatan Daerah Kabupaten Minahasa Utara.

\section{Tempat dan Waktu Penelitian}

Penelitian ini dilakukan pada Instansi Pemerintahan di Dinas Pendapatan Daerah Kabupaten Minahasa Utara di Komplek Perkantoran Kabupaten Minahsa Utara. Waktu penelitian ini dilakukan pada bulan April 2016 sampai selesai.

\section{Prosedur Penelitian}

Langkah-langkah yang dilakukan dalam penelitian ini sebagai berikut:

1. Mengumpulkan teori-teori

2. Memilih prosedur dan teknik yang dilakukan

3. Mencari data yang digunakan

4. Memberikan kesimpulan dan saran

\section{Objek Penelitian}

Objek penelitian dalam penelitian ini adalah Penerimaan PAD pada Dinas Pendapatan Daerah Kabupaten Minahasa Utara, lebih Khususnya di Bidang Perencanaan dan Pengembangan, dan Di Sekretariat Dinas Pendapatan Daerah Kabupaten Minahasa Utara untuk mendapatkan data Sistem Pengendalian Intern Pemerintah.

\section{Metode Pengumpulan Data}

Pengumpulan data dilakukan untuk memperoleh informasi yang dibutuhkan dalam rangka mencapai tujuan penelitan, maka metode pengumpulan data yang digunakan adalah pengumpulan data sekunder dan teknik yang digunakan survei pendahuluan, studi lapangan dan studi kepustakaan.

\section{Metode Analisis}

Metode analisis yang dipakai dalam penelitian ini adalah metode deskriptif. Metode Deskriptif adalah suatu metode penelitian yang menggambarkan semua data atau keadaan subyek/obyek penelitian (seseorang, lembaga, masyarakat dan lain-lain) kemudian dianalisis dan dibandingkan berdasarkan kenyataan yang sedang berlangsung pada saat ini dan selanjutnya mencoba untuk memberikan pemecahan masalahnya. Menurut Widi (201: 84) Penelitian deskriptif merupakan penelitian yang berusaha mendeskripsikan dan menginterpretasikan sesuatu, misalnya kondisi atau hubungan yang ada, pendapat yang berkembang, proses yang sedang berlangsung, akibat atau efek yang terjadi, atau tentang kecerendungan yang tengah berlangsung. Penelitian deskriptif adalah penelitian yang dirancang untuk memperoleh informasi tentang status suatu gejala saat penelitian dilakukan. Lebih lanjut dijelaskan, dalam penelitian deskriptif tidak ada perlakuan yang diberikan atau dikendalikan serta tidak di uji hipotesis sebagaimana yang terdapat pada penelitian eksperiman.

Langkah-langka yang dilakukan dalam menganalis data adalah sebagai berikut. 
1. Melakukan perbandingan antara Sistem Pengendalian Intern Pemerintah Nomor 60 Tahun 2008 dengan Sistem Pengendalian Intern yang ada dalam Dinas Pendapatan Daerah di Kabupaten Minahasa Utara

2. Menguji efektivitas sistem pengendalian internal pada kinerja Instansi Pemerintah di Dinas Pendapatan Daerah Kabupaten Minahasa Utara.

\section{Hasil Penelitian}

\section{Capaian Kinerja Organisasi}

Dalam pencapaian kinerja Dinas Pendapatan Daerah Kabupaten Minahasa Utara secara berkelanjutan tetap melaksanakan program dan kegiatan yang mendorong peningkatan pengelolaan penerimaan daerah. Untuk mengimplementasikan kinerja yang telah tercapai oleh Dinas Pendapatan Daerah Kabupaten Minahasa Utara dapat dilihat dalam rincian sebagai berikut.

Table 4.1

Target dan Realisasi Penerimaan Pendaapatan Daerah Kabupaten Minahasa Utara Tahun 2015

\begin{tabular}{|r|l|r|r|r|}
\hline No & \multicolumn{1}{|c|}{ Jenis Penerimaan } & \multicolumn{1}{|c|}{ Target $(\mathbf{R p )}$} & \multicolumn{1}{c|}{ Realisasi (Rp) } & \multicolumn{1}{c|}{$\boldsymbol{\%}$} \\
\hline 1 & Pajak & 22.925 .000 .000 .00 & 25.266 .469 .042 .00 & 110.21 \\
\hline 2 & Retribusi & 9.078 .250 .000 .00 & 8.686 .125 .519 .00 & 95.68 \\
\hline 3 & HPKD yang dipisahkan & 687.312 .587 .00 & 687.312 .587 .00 & 100.00 \\
\hline 4 & Lain-lain PAD yang Sah & 20.837 .121 .251 .00 & 20.386 .821 .418 .00 & 97.84 \\
\hline
\end{tabular}

Sumber : Dinas Pendapatan Daerah Kab. Minahasa Utara

Dari data diatas bisa kita lihat bahwa seluruh jenis penerimaan pemerintah daerah kabupaten minahasa utara baik dari pajak daerah, retribusi daerah, hasil pengelolaan kekayaan daerah yang dipisahkan dan lain-lain PAD yang sah telah mencapai target yang ditetapkan pemerintah. Penerimaan daerah melalui pajak dari target Rp. 22.925.000.000.00 bisa tercapai Rp.25.266.469.042.00, Retribusi dengan target Rp.9.078.250.000.00 tidak tercapai Rp.8.686.125.519.00, pendapatan Hasil Pengelolaan Kekayaan Daerah yang dipisahkan dengan target Rp.687.312.587.00 bisa tercapai dengan realisasi Rp.687.312.587.00, dan Lain-lain Pendapatan Asli Daerah yang sah dengan target Rp.20.837.121.251.00 tidak tercapai Rp.20386.821.418.00 kalau ditotalkan keseluruhan, penerimaan pendapatan daerah adalah Target Rp.53.527.683.838.00 dan Realisasi 55.026.728.566.00 dengan Persentase 102.80.

\section{Sistem Pengendalian Intern Pemerintah pada Kinerja Instansi pemerintah di Dinas Pendaptan Daerah Kabupaten Minahasa Utara}

Dalam hasil yang didapat penulis dengan melakukan wawancara secara lisan dan tulisan untuk memperoleh gambaran sejauh mana efektivitas pengendalian intern pada kinerja maka dalam pengawasan yang dilakukan Dinas Pendapatan Daerah Kabupaten Minahasa Utara harus berdasarkan pada Peraturan Pemerintah RI Nomor 60 Tahun 2008 tentang Sistem Pengendalian Intern Pemerintah (SPIP). Hasil indikator wawancara meliputi lima unsur SPIP sebagai berikut.

1. Lingkungan Pengendalian

Dalam lingkungan pengendalian, Dinas Pendapatan Daerah Kabupaten Minahasa Utara sudah melaksanakan penerapan sistem pengendalian intern dalam lingkungan kerjanya melalui pimpinan dan pegawai telah memiliki sikap perilaku yang positif dan mendukung pengendalian intern dan manajemen yang bersih, pimpinan juga telah menyampaikan pesan bahwa nilai-nilai integritas dan etis tidak boleh dikompromikan, pimpinan juga menunjukan suatu komitmen terhadap kompetensi/kemampuan pegawainya dan menggunakan kebijakan dan praktik pembinaan sumber daya manusia yang baik, pimpinan memiliki kepemimpinan yang kondusif yang mendukung pengendalian intern yang efektif, struktur organisasi dan metode pendelegasian wewenang dan tanggung jawab memberikan kontribusi terhadap efektivitas 
pengendalian intern dan Dinas Pendapatan Daerah Kabupaten Minahasa Utara telah memiliki hubungan kerja yang baik dengan badan legislatif serta auditor internal dan eksternal.

2. Penilaian Resiko

Penilaian risiko adalah kegiatan penilaian atas kemungkinan kejadian yang mengancam pencapaian tujuan dan sasaran Instansi Pemerintah. Penilaian resiko yang perlu dipertimbangkan dan dilakukan Dinas Pendapatan Daerah Kabupaten Minahasa Utara sudah menetapkan tujuan keseluruhan yang jelas dan konsisten serta tujuan tingkatan kegiatan yang mendukung, pimpinan juga telah melakukan identifikasi resiko secara menyeluruh mulai dari sumber internal dan eksternal yang dapat mempengaruhi kemampuan untuk mencapai tujuan Dinas Pendapatan Daerah Kabupaten Minahasa Utara lalu melakukan analisis resiko untuk mengelola resiko, selain itu Dinas Pendapatan Daerah Kabupaten Minahasa Utara mengidentifikasi perubahan yang dapat mempengaruhi kemampuan untuk mencapai visi, misi dan tujuannnya.

3. Kegiatan Pengendalian

Kegiatan pengendalian adalah tindakan yang diperlukan untuk mengatasi risiko serta penetapan dan pelaksanaan kebijakan dan prosedur untuk memastikan bahwa tindakan mengatasi risiko telah dilaksanakan secara efektif. Kegiatan pengendalian yang dilakukan di Dinas Pendapatan Daerah Kabupaten Minahasa Utara meliputi kebijakan, prosedur, teknik dan mekanisme pengendalian yang memadai sudah dikembangkan dan sudah diterapkan untuk memastikan adanya kepatuhan terhadap arahan yang sudah ditetapkan.

4. Informasi dan Komunikasi

Informasi adalah data yang telah diolah yang dapat digunakan untuk pengambilan keputusan dalam rangka penyelenggaraan tugas dan fungsi Instansi Pemerintah. Komunikasi adalah proses penyampaian pesan atau informasi dengan menggunakan simbol atau lambang tertentu baik secara langsung maupun tidak langsung untuk mendapatkan umpan balik. Informasi dan komunikasi yang dilakukan pada Dinas Pendapatan Daerah Kabupaten Minahasa Utara mulai dari sistem informasi untuk mengidentifikasi dan mencatat informasi operasional dan keuangan yang penting yang berhubungan dengan peristiwa internal dan eksternal tealah ada dan diimplementasikan kemudian informasi tersebut dikomunikasikan kepada pimpinan Dinas Pendapatan Daerah Kabupaten Minahasa Utara dan pegawai Dinas Pendapatan Daerah Kabupaten Minahasa Utara untuk melaksanakan tugas dan tanggung jawab secara efektif dan efisien. Pimpinan Dinas Pendapatan Daerah Kabupaten Minahasa Utara telah memastikan bahwa komunikasi internal telah terjalin dengan efektif dan pimpinan juga harus memastikan bahwa komunikasi eksternal yang efektif akan mempengaruhi pencapaian visi, misi dan tujuan organisasi. Pimpinan Dinas Pendapatan Daerah Kabupaten Minahasa Utara telah menggunankan berbagai bentuk komunikasi yang sesuai dengan kebutuhan dan memperbaharui sistem informasi dalam upaya meningkatkan konikasi.

5. Pemantauan Pengendalian Intern

Pemantauan pengendalian intern adalah proses penilaian atas mutu kinerja Sistem Pengendalian Intern dan proses yang memberikan keyakinan bahwa temuan audit dan evaluasi lainnya segera ditindaklanjuti. Evaluasi adalah rangkaian kegiatan membandingkan hasil/prestasi suatu program/kegiatan dengan norma, standar, dan prosedur yang telah ditetapkan dan menentukan faktor-faktor yang mempengaruhi keberhasilan atau kegagalan suatu program/kegiatan dalam mencapai tujuan. Dinas Pendapatan Daerah Kabupaten Minahasa Utara secara berkesinambungan melakukan pemantauan pengendalian intern untuk menilai kualitas kinerja dan evaluasi terhadap capaian kinerja organisasi Dinas Pendapatan Daerah Kabupaten Minahasa Utara ssecara berkala dengan tujuan mengetahui kekuatan dan kelemahan yang ada dalam capaian kinerja organisasi, sehingga dapat diupayakan pengendalian internal yang lebih baik.

\section{Pembahasan}

\section{Capaian Kinerja Organisasi}

Berdasarkan hasil penelitian dapat diketahui bahwa jumlah penerimaan tahun 2015 sudah efektif karena target dari Dinas Pendapatan Daerah Kabupaten Minahasa Utara melebihi dari yang direncanakan. Jadi sistem pengendalian intern pemerintah dalam pencapaian kinerja organisasi sudah 
efektif. Dengan adanya sistem pengendalian intern yang baik maka kecurangan dalam penerimaan dapat dihindari.

Pengendalian intern yang diterapkan pada Dinas Pendapatan Daerah Kabupaten Minahasa Utara sangat berperan penting terhadap pencapaian kinerja organisasi, hal ini dapat dilihat dari tercapainya tujuan pengendalian intern yang sangat berpengaruh terhadap efektivitas capaian kinerja organisasi pada instansi pemerintah di Dinas Pendapatan Daerah Kabupaten Minahasa Utara. Hasil yang didapat dalam pengendalian intern adalaha sebagai berikut.

1. Mendorong Efisiensi dan Efektivitas.

Dinas Pendapatan Daerah Kabupaten Minahasa Utara telah melakukan sistem pengendalian intern sehingga capaian kinerja organisasi dikatakan efektif atau tercapai.

2. Mendorong Pengamanan Aset Daerah.

Dinas Pendapatan Daerah Kabupaten Minahasa Utara telah bekerja keras untuk meningkatkan sumber penerimaan pendapatan agar semua belanja daerah bisa dibiayai.

3. Mendorong Keandalan Laporan Keuangan.

Dinas Pendapatan Daerah Kabupaten Minahasa Utara melakukan Pengendalian Intern yang dilakukan beserta tindak lanjutnya secara langsung mengawasi transaksi yang terjadi sehingga data keuangan yang sah menjadi pendukung laporan keuangan yang bebas dari salah saji. Laporan keuangan juga berpedoman pada prinsip akuntansi yang berlaku umum.

4. Mendorong Ketaatan Terhadap Peraturan Perundang-Undangan.

Dinas Pendapatan Daerah Kabupaten Minahasa Utara selalu berupaya menaati segala peraturan dan hukum yang berlaku terutama mengenai aturan-aturan sistem penerimaan yang di tetapkan oleh Dinas Pendapatan Daerah Kabupaten Minahasa Utara guna mencegah timbulnya sanksi, selain itu kepala dinas dengan integritas dan nilai etika yang dimiliki telah memberikan contoh yang baik bagi pegawainya dengan menjalankan tugas sesuai tanggung jawab dan wewenang yang dimiliki.

Hasil penelitian yang dilakukan oleh penulis menunjukan bahwah dengan adanya Penerapan Sistem Pengendalian Intern Pemerintah maka pengelolaan keuangan daerah pada isntansi pemerintah terkait dapat berjalan dengan baik, hal ini sejalan dengan penelitian yang dilakukan sebelumnya oleh Kaligis (2015), Turwidani (2015), Iskandar (2015) pada Dinas Pendapatan Daerah kota Bitung dan Kota Pariaman, serta tercapainya penyelenggaraan kegiatan pemerintah yang efektif dan efisien sehingga kinerja Dinas Pendapatan Daerah bisa berjalan dengan baik hal ini juga sesuai dengan penelitian sebelumnya yang dilakukan oleh Tresnawati (2012), Situmorang (2012) pada pemerintah di Dinas Pendapatan Kota Bandung dan Kota Sorong.

\section{Kesimpulan}

\section{PENUTUP}

Kesimpulan penelitian ini adalah :

1. Sistem pengendalian intern yang diterapkan oleh Instansi Pemerintahan di Dinas Pendapatan Daerah Kabupaten Minahasa Utara telah efektif dan memadai. Karena telah sesuai dengan Sistem Pengendalian Intern Pemerintah yang telah ditetapkan oleh pemerintah berdasarkan Peraturan Pemerintah Nomor 60 Tahun 2008.

2. Pencapaian Penerimaan Pendapatan dan Realisasi daerah tahun 2015 sudah efektif.

3. Pemisahan tugas yang dilakukan Dinas Pendapatan Daerah Kabupaten Minahasa Utara sudah dilaksanakan sehingga terhindar dari kecurangan dan dikatakan efektif.

\section{Saran}

Saran yang dapat diberikan adalah :

1. Sistem pengendalian pemerintah yang telah ada di Dinas Pendapatan Daerah Kabupaten Minahasa Utara diharapkan untuk dipertahankan agar efektivitas kinerja Dinas Pendapatan Daerah Kabupaten Minahasa Utara bias mencapai maksimal

2. Untuk peneliti selanjutnya, yang ingin melakukan penelitian tentang sistem pengendalian intern pemerintah agar memperbaharui literature dan undang-undang yang ada, berhubung sistem pengendalian intern pemerintah yang sewaktu-waktu dapat di ubah/revisi. 
3. Dinas Pendapatan Daerah Kabupaten Minahasa Utara diharapkan dapat terus memotivasi pegawainya agar lebih meningkatkan kinerja dan kemampuannya serta lebih memperahtikan keluhan-keluhan yang disampaikan agar pegawai lebih berusaha serta memberikan hasil yang baik agar kinerja Dinas Pendapatan Daerah Kabupaten Minahasa Utara dapat meningkat dan target dapat tercapai.

\section{DAFTAR PUSTAKA}

Damayanti, Indah Ayu 2015. Analisis efektivitas dan kontribusi penerimaan pajak bumi dan bangunan terhadap pendapatan asli daerah di kota Denpasar. E-Jurnal Akuntansi Universitas Udayana.Vol. 9, No.1, Oktober 2014.

Deddi, 2012. Wiratna Akuntansi sektor publik, pengertian akuntansi pemerintahan. Pustaka baru press Halim et, al, 2014. Wiratna Akuntansi sektor publik, pengertian akuntansi pemerintahan. Pustaka baru press

Halim Abdul. 2013. Akuntansi Keuangan Daerah. Edisi keempat. Salemba empat. Jakarta

Iskandar, Joni. 2015. Pengaruh Sistem Pengendalian Intern Pemerintah, Kompetensi Sumber Daya Manusia Dan Pengawasan Fungsional Terhadap Efektivitas Pengelolaan Keuangan Daerah. Fakultas Ekonomi. Universitas Riau. Pekanbaru. Jom FEKON Vol. 2 No. 2. http://id.portalgaruda.org/?ref=browse\&mod=viewarticle\&article=384810. Diakses Februari 252016.

Kaligis, Gabriella Margaretha (2015). Analisis penerapan system pengendalian intern kas pada Dinas Pendapatan Daerah Kota Bitung. Jurnal Berkala Ilmiah Efisiensi Volume 15 No. 04. Unsrat manado. Fakultas Ekonomi dan Bisnis. http://ejournal.unsrat.ac.id/index.php/jbie/article/view/9765. diakses februari 25,2016

Mahsun, Muhamad. 2014. Pengukuran Kinerja Sektor Publik. BPFE-Yogyakarta

Mahmudi. 2010. Manajemen kinerja sektor publik edisi kedua. UPP STIM. YKPN. Yogyakarta

Matamande, Wilson, Nyikahadzoi Loveness, Taderera Ever, Mandimika Elinah. 2012. The effectiveness of internal controls in revenue management: A case study of Zimbabwe Revenue Authority (ZIMRA) (2011-2012). University of Zimbabwe.Zimbabwe. http://www.aabri.com/manuscripts/131525.pdf. Diakses maret 1,2016.

Nordiawan, 2012. Wiratna Akuntansi sektor publik, pengertian akuntansi pemerintahan. Pustaka baru press

Pontoh, Winston, 2013. Akuntansi Konsep dan Aplikasi.HalamanMoeka. Jakarta Barat.

Puspitasari, Elfayang Rizky Ayu (2014). Analisis Efektivitas, Efisiensi, Dan Kontribusi Pajak Daerah Dan Retribusi Daerah Terhadap Peningkatan Pad Kabupaten Blora Tahun 2009-2013. Diponegoro Journal Of Accounting Volume 3 Nomor 4. http://ejournals1.undip.ac.id/index.php/accounting. Diakses 26,februari,2016

Putri, E.T. (2014). PENGARUH KARAKTERISTIK PEMERINTAH DAERAH TERHADAP KINERJA KEUANGAN PEMERINTAH DAERAH (Studi pada Pemerintah Provinsi di Indonesia Tahun 2008 - 2012). Universitas Lampung. Bandar Lampung. http://digilib.unila.ac.id/2553/16/BAB\%20II.pdf. Diakses Februari,25,2016

Republik Indonesia. 2008. Peraturan Pemerintah No 60 Tahun 2008 Tentang Sistem Pengendalian Intern Pemerintah

Republik Indonesia. 2014. Undang-Undang Nomor 23 Tahun 2014 Tentang Pemerintah Daerah.

Republik Indonesia. 2015. Undang-Undang Nomor 9 Tahun 2015 Tentang Pemerintah Daerah

Republik Indonesia. 2004. Undang-Undang Nomor 33 Tahun 2004 Tentang Perimbangan Keuangan Antara Pemerintah Pusat dan Daerah

Republik Indonesia. 2004. Undang-Undang Nomor 1 Tahun 2004 Tentang Perbendaharaan Negara

Republik Indonesia. 1996. Kepmendagri No 690.900-327 Tahun 1996 Tentang Pedoman Penilaian dan Kinerja Keuangan.

Sadeli, Lili M, 2014. Dasar-Dasar Akuntansi. Edisi Pertama. BumiAksara.Jakarta

Sari, Ni Luh Putu Purnama 2015. Pengaruh Efektifitas Sistem Pengendalian Internal, Ketaatan Aturan Akuntansi, Persepsi Kesesuaian Kompensasi Dan Implementasi Good Governance Terhadap Kecenderungan Fraud. e-Journal S1 Ak Universitas Pendidikan Ganesha Jurusan Akuntansi Program S1 (Volume 3, No.1 Tahun 2015) 
Situmorang, Enny (2012). Efektivitas Pengendalian Intern (Internal Control) Terhadap Kinerja Dinas Pendapatan Daerah Kota Sorong. Fakultas Ekonomi. Univrsitas Sam Ratlangi. Manado.

Sugiyono. 2012. Memahami penelitian kualitatif. Bandung. ALFABETA

Sujarweni, V Wiratna (2015). Akuntansi Sektor Publik. Penerbit Pustaka Baru Press. Yogyakarta.

Tresnawati, Rina (2012). Pengaruh Efektifitas Pengendalian Intern Terhadap Kinerja Instansi Pemerintah Di Dinas Pendapatan Daerah Kota Bandung. Universitas Widyatama, Lembaga Penerbitan Laboraturium Akuntansi, Fakultas Pendidikan Ekonomi \& Bisnis

Turwidani, Lopita. 2015. Pengaruh Sistem Pengendalian Intern Pemerintah, Kompetensi Sumber Daya Manusia, Sistem Akuntansi Keuangan Derah Dan Pengawasan Fungsional Terhadap Efektivitas Pengelolaan Keuangan Daerah. Fakultas Ekonomi. Universitas Riau. Jom FEKON Vol. 2 No. 2.

Widi, Restu Kartiko (2010). Asas Metodologi Penelitian. Edisi Pertama. Graha ilmu. Yogyakarta 